\title{
State of the Art of Switched Reluctance Generator
}

\author{
Amissa Arifin, Ibrahim Al-Bahadly, Subhas Chandra Mukhopadhyay \\ School of Engineering and Advanced Technology, Massey University, Palmerston North, New Zealand \\ Email: a.arifin@massey.ac.nz
}

Received August 28, 2012; revised September 30, 2012; accepted October 12, 2012

\begin{abstract}
This paper provides a comprehensive review of the recent development on the switched reluctance machine operating in generating mode in both the low and high speed operations. The machine consists of a salient rotor and stator poles and controlled via switching of the power electronic devices. There is a steady development of the machine operating in the motoring mode; however, its generating operation is still under study. This paper gives an overview of the machine, followed by the principle of operation in generating mode and briefly discusses the structure and types of control methods which involve the switched reluctance generator (SRG). Due to its geometry simplicity and advantages such as robust, ability to operate over a wide speed range and absence of permanent magnet and windings on the rotor, the SRG promises to be a good candidate for variable speed application.
\end{abstract}

Keywords: Switched Reluctance Generator (SRG); SRG Control; SRG Converter Circuit; SRG Structure

\section{Introduction}

One of the earliest motor during the 1830s was the reluctance motor based on the concept of electromagnet. Its development was hindered due to the requirements of complicated control circuits and high cost of power electronic devices. Furthermore, the emergence of a commutator motor in 1870s and the introduction of the magnetic circuit law in 1880s has given way to motors that outweigh the performance of the reluctance motor [1]. The Switched Reluctance Machine (SRM) made its come back only in 1960s due to the rapid development of power electronic devices and also the availability of high speed computers coupled with advance programming languages [1].

The SRM is referred to as a doubly salient pole due to the salient pole of its stator and rotor structure [2]. Salient pole refers to the structure of the element protruding from the yoke into the air gap. The rotor and the stator are made of steel laminations, and only the stator poles have windings concentrated around it [3]. The rotor, on the other hand, is free from windings, magnets and brushes. The windings on one of the stator pole are connected in series with the opposite stator to form one phase. It can be arranged in such a way that more than 2 opposite stator poles can form one phase. The typical configuration of the machine includes 3 phase 6 stator or 4 rotor (6/4) or $12 / 8$ and 4 phase $8 / 6$ or $16 / 12$. Figure 1(a) is showing an example of the 4 phase SR machine with $8 / 6$ poles configuration while Figure 1(b) is showing a 3 phase machine with $12 / 8$ poles configu- ration.

The following characteristics of the SRM have attracted researchers to investigate its potential for variable speed application:

- Simplified construction with rotor only consists of laminated steel;

- Concentrated phase winding is only on the stator poles;

- Absence of permanent magnet which gives low manufacturing cost;

- Machine can operate at high speed and high temperature operation since the rotor can act as a cooling source to the stator;

- Has higher reliability since each phase is electrically and magnetically independent;

- Low inertia since it does not have windings or magnets on the rotor hence machine can operate at low wind speed and respond to rapid variations in loads [4].

The operation of SRM depends entirely on synchronized excitation of the set of stator windings to create continuous rotation of the rotor poles [3]. The movement of the rotor with respect to the excited stator phase varies the inductance of the machine periodically from maximum, where rotor and stator poles are aligned, to minimum unaligned rotor and stator poles. The inductance is maximum at the aligned position and minimum during the unaligned position. By proper positioning of current pulses, the machine can operate either as:

- motor during increasing inductance profile or as; 

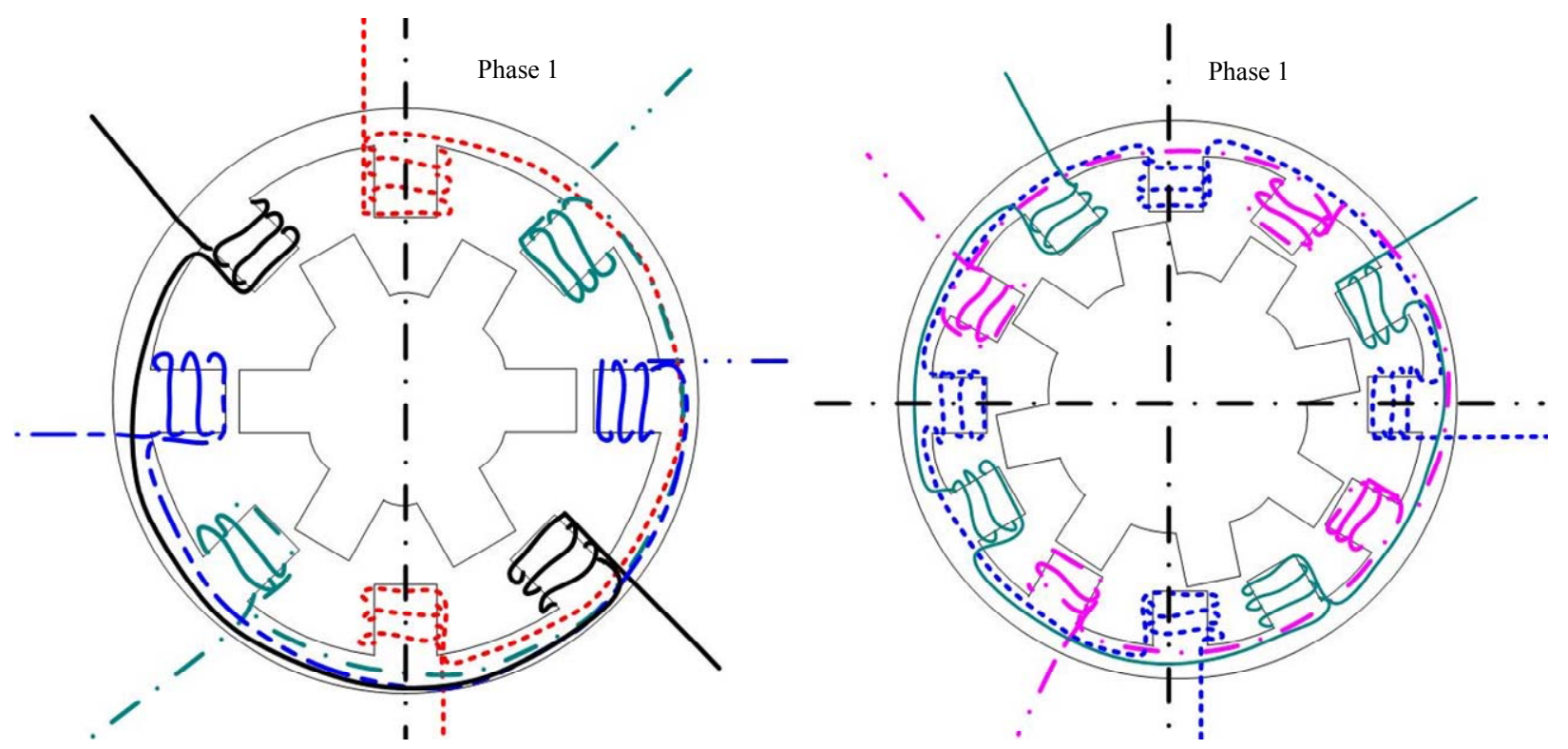

Figure 1. Configuration of a switched reluctance machine: (a) 4 phase 8/6 and (b) 3 phase 12/8 .

- generator during decreasing inductance profile.

Various literatures are available on the motoring operation which covers almost all aspects such as fault [5-7], application [8,9], structure [10,11], control [12,13] and also on sensorless rotor detection $[14,15]$. Its commercial application can be seen in vacuum cleaner, refrigerator, washing machine and also electric vehicles. We can conclude that the operation of SRM as motor has made a good progress; however, despite its advantages the operation in generating mode is slowly evolving.

While there are a number of papers on switched reluctance generator (SRG) being published, a comprehensive overview of the machine operating as a generator has not yet been published. Therefore, this paper makes an attempt to give an overview and highlight the recent development of the machine in generating mode. The paper is arranged such that section one discusses the operating principles of the SRG. The following sections include the machine structure, application, control and converter topologies employed for the generating mode.

\section{SRG Operating Principles}

The switched reluctance machine (SRM) has close similarity with a stepper motor in terms of its operation; however it differs in structure, control method and applications. While a stepper motor has multiple tooth permanent magnet type rotor arranged in a gear shaped piece of iron, the SRM has fewer numbers of poles and free of magnets. Due to the machine not having a permanent magnet, the magnetic field within the machine has to be created using an external supply. Because of this, the SRM drive requires a separate excitation circuit which is connected directly to the windings on the stator poles. The machine, therefore, relies on a single excitation source; a battery, a magnet or a charged capacitor with an initial voltage placed in series with the load [16]. As a generator, the SRM is designed for energy conversion system whereas the stepper motor is for position control. The Switched Reluctance Generator drive consists of the machine itself, the converter and also the controller as depicted in Figure 2.

The operation of the machine is based on the principle that the rotor, driven by a prime mover, is free to move to a position of minimum reluctance to the flow of flux in a magnetic circuit. This is achieved by energizing and de-energizing a set of windings on the stator poles. Since an external circuit is required to provide excitation to the stator winding of the machine, it does not allow direct connection to an AC or DC supply. The operation cycle of the machine can be classified as excitation stage and generation stage. The excitation methods available in the literature is the self-excitation [17] and separate excitation [4]. The former is commonly employed whereas the latter requires a different bus line, separating the excitation and generation stage [18]. An essential component of the machine to perform switching sequence, exciting the stator phase in synchronism with the rotor position is the power converter. In generating operation, the machine is controlled in such a way that it operates along the decreasing inductance profile as shown in Figure 3.

As can be seen, in Figures 3(a)(i) and (b) the rotor and stator is in the aligned position with maximum inductance. Excitation of stator phase must be made when rotor is moving pass the stator as shown in Figures 3(a)(ii) and (b). In contrast to the motoring operation, the 
excitation is performed during the minimum, and along the increasing inductance region whilst the rotor and stator pole is unaligned as in Figure 3(a)(iii). When voltage is applied across the stator phase winding, current flows through the winding, creating magnetic flux. This magnetic flux crosses the air gap between the stator and rotor poles. This in turn, induces magnetization in the rotor poles and cause variation of flux in the stator windings [19]. The movement of rotor in an out of alignment with the stator poles creates variation of reluctance flux path, proportional to energy conversion [20]. In every cycle, the flux must be established and returned to zero before excitation of the next phase.

As the rotor moves towards or away from the excited stator phase, torque $(T)$ which is shown by equation below is created.

$$
T=\frac{1}{2} i^{2} \frac{\mathrm{d} L}{\mathrm{~d} \theta}
$$

The torque is independent of phase current, $i$ but relies on the slope of inductance profile. The excitation of the stator phase during unaligned position as in Figure 3(a)(iii) will not produce torque since $\frac{\mathrm{d} L}{\mathrm{~d} \theta}$ is zero. However, if the stator phase is excited as the rotor is moving pass the stator pole as in Figure 3(a)(ii) there will be a braking torque trying to realign the poles back together. This creates a negative torque, extracting energy from the prime mover during generating mode.

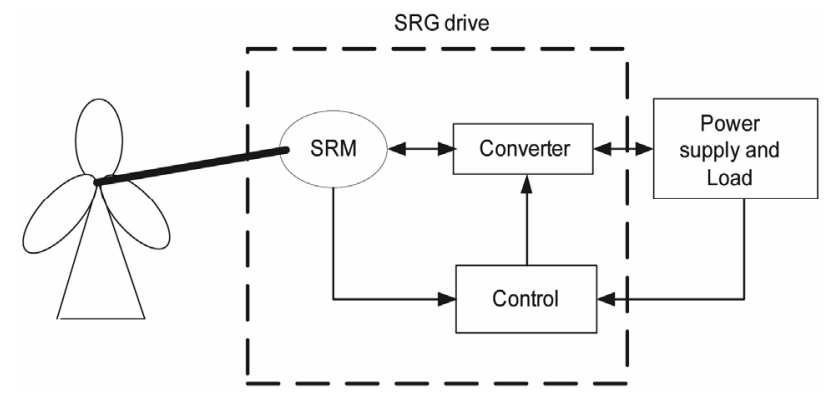

Figure 2. A simplified diagram showing the main components which form the SRG system.

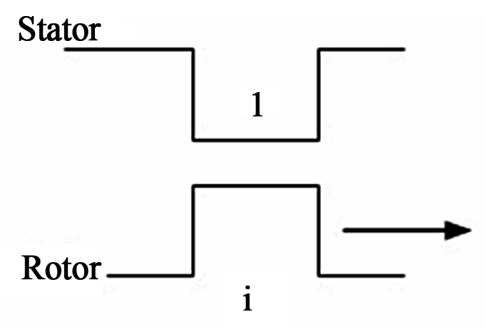

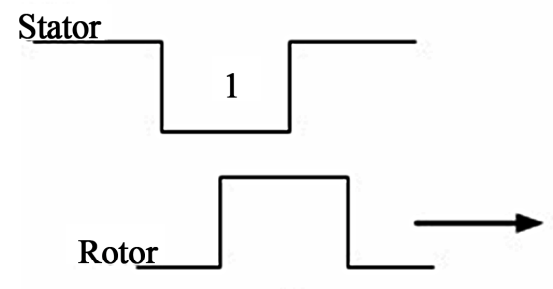

ii
Stator

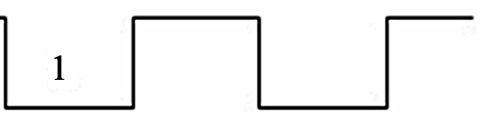

(a)

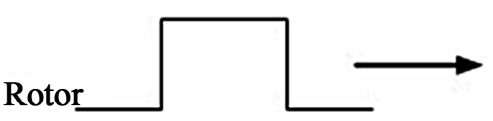

iii

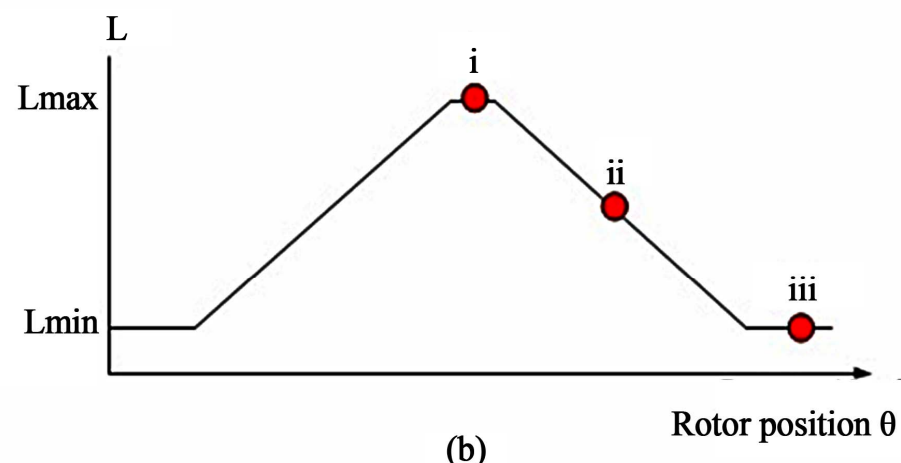

(b)

Figure 3. Variation of inductance with respect to movement of rotor. (a) Rotor movement with respect to stator pole: (i) Maximum inductance, minimum reluctance (full alignment); (ii) Inductance decreasing linearly; (iii) Minimum inductance (mis-alignment); (b) Complete inductance profile with respect to rotor position. 


\section{Applications of SRG}

The simple construction of the machine leading to a low manufacturing cost has widened the acceptance of the machine. The features of the machine such as having the ability to operate under faulted condition, robust to harsh operational conditions and having a high power density has extended the motoring operation from domestic appliances to the traction applications [21] and automotive industries for hybrid vehicles [22-25]. The application of the machine as a generator concentrates more on high speed applications where it was used as starter/generators for the aircraft industries $[9,26-30]$ and the automotive industries [31,32].

\subsection{High Speed}

In the automotive industry, the electrical load requirement has increased due to the introduction of electronically driven systems such as powered window, power steering, active suspensions, lights and pumps to improve comfort and safety features of the vehicles. The existing voltage level will not be able to cope with the increase of load hence a higher voltage is required [33]. This has introduced the concept of "more electric car" with requirements of an efficient, compact and reliable generation system. The conventional starter motor and alternator has been replaced by a single device; the integrated starter generator/alternator for integration with the internal combustion engine [34,35]. The combined product produces higher power and efficiency, mainly used in the development of the electric vehicles [36] and hybrid electric vehicles (HEV) [37,38].

The aircraft subsystems are previously powered by the hydraulic, pneumatic or mechanical means nowadays utilize the electric power [39]. The limitations of the conventional method to drive the subsystems failed to accommodate the increase in electrical energy required by the power electronic devices installed on the aircraft. The combinations of the electric power with power electronic components are believed to have increased the performance in terms of reliability, fault tolerance and also power density [40]. The reliability and the safety aspects of the aircraft system can be increased by performing simultaneously operation using two channels of the same phase. Since the excitation of each phase is performed independently, a fault or transient in one of the channels does not have an effect on the other channel [41].

\subsection{Low Speed}

Amongst the growing potential, of renewable energy nowadays is the wind energy which account for the 3\% of the world's electricity demand. It can be categorized into two groups: large wind turbine (LWT) and small wind turbine (SWT). The former provides generation of electricity from large grid connected wind farms [42] whereas the latter has been applied for off grid supply [43] in various fields such as road lighting, mobile communication base tower and also for individual housing consumer. In developed countries such as the USA, the SWT is employed to supply electricity to remote regions. However, there is great potential to use the SWT in a fully developed area where there is limited space for the expansion of power supply as it can be placed in areas such as roof top. Although the industrial scale is far behind as compared to the LWT, its contribution to the power generation is equally important. The on-going studies regarding the use of SRG for wind energy application proves it as a potential candidate alongside the conventional machines [17,44-47]. The existing technologies for wind energy applications include the permanent magnet (PM) generators, doubly fed induction generator (DFIG), synchronous generators and also the squirrel cage induction generator [48]. However, the existing generators has its shortcomings such as the squirrel cage induction generator operates at constant speed as well as having large values of the capacitor to attain the power factor close to one. The issues with using permanent magnet are the high cost and the demagnetization of the material [49]. Also, it operates on high torque, which is a disadvantage at a lower speed [17]. The induction machine though is robust and requires less maintenance produce low efficiency. There are concerns over safety system for DFIG during fault conditions due to the small/ limited converter rating on the rotor side as compared to the DC link converter [50].

On the whole, the acceptance of the machine as a generator has sparked an in-depth research into areas such as the control strategies, optimization method, and machine structure and also on converter topologies. The discussions in the subsequent sections will be based upon the applications mentioned above.

\section{Structure of the Stator and Rotor Pole}

The numbers of the stator and rotor poles are designed to avoid the zero torque regions. This leads to the design of the machine having a symmetrical and equally spaced number of stator and rotor poles [51]. The periodic cycle of one rotor position decreases as the number of rotor poles increase shown below where $N_{r}$ is the number of rotor poles.

$$
1 \text { cycle of rotor position }=\frac{2 \pi}{N_{r}}
$$

Taking an example between a 12/8 and 12/16 machine having the same number of turns, current density in the 
winding and stator dimensions, the inductance profile of the higher rotor poles is narrow as compared to the machine with lower number of rotor poles. Therefore, a higher number of rotor poles machine will require more excitation as seen in Figures 4(a) and (c). Nevertheless, it gives better torque profile than the machine with lower number of poles as depicted in Figure 4(d). The average torque, $T_{\text {ave }}$ of the machine can be represented in terms of the energy conversion loop:

$$
T_{\text {ave }}=\frac{S W}{2 \pi}
$$

where $S$ is the number of strokes per revolution and $W$ is the area corresponding to the conduction interval for each phase in the magnetization curve. The number of strokes can be written as:

$$
S=m N_{r}
$$

$N_{r}$ is the number of rotor poles and $m$ is the number of phase. The energy conversion loop reduces as the number of rotor poles is increased. To analyze the machine structure for both the high and low speed, the voltage across the phase winding, neglecting the winding resistance is represented as:

$$
V=N \frac{\mathrm{d} \psi}{\mathrm{d} \theta} \frac{\mathrm{d} \theta}{\mathrm{d} t}
$$

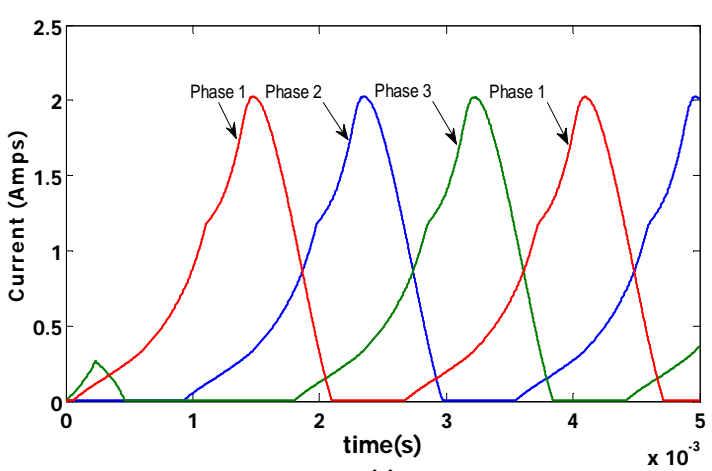

(a)

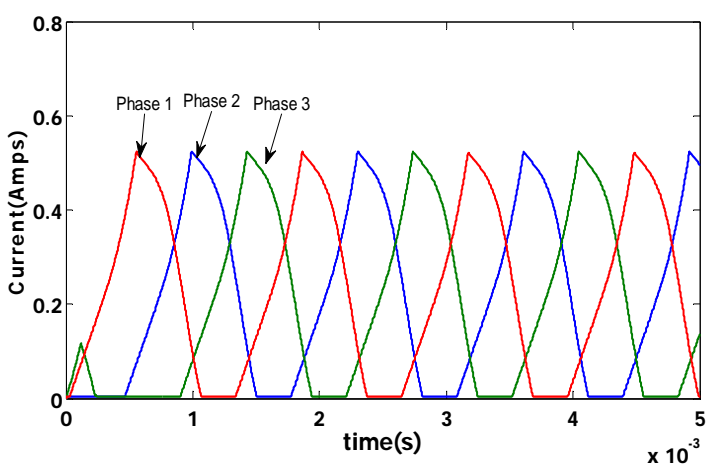

(c)

\subsection{High Speed}

When the voltage $V$ and number of turns, $N$ is constant, the time for the flux to build up at high speed is shorter, resulting in a low $\frac{\mathrm{d} \psi}{\mathrm{d} \theta}$. Therefore, lower number of poles machine has been suggested for a high speed application whereas the high number of poles for a low speed application $[3,47]$. The reason being, lower number of poles has larger conduction/dwell angles thus allowing the flux to reach its desired level at high speed. Also, according to Equations (3) and (4) the lower number of poles provides higher generated energy due to the larger energy curve.

\subsection{Low Speed}

In contrast to the high speed application, the magnetic flux at lower speed requires longer time to build up resulting in a high increase of $\frac{\mathrm{d} \psi}{\mathrm{d} \theta}$ [52]. Therefore, a high number of poles are suggested for low speed to avoid saturation in the machine. However, having a higher number of poles will reduce the energy conversion curve hence the generated energy. Also, the aligned to unaligned inductance ratio is reduced. This will lead to a high peak current resulting in higher converter VA requirement [53].

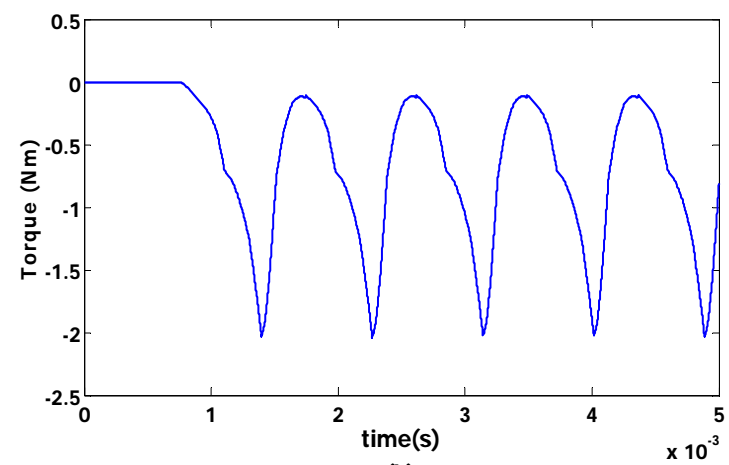

(b)

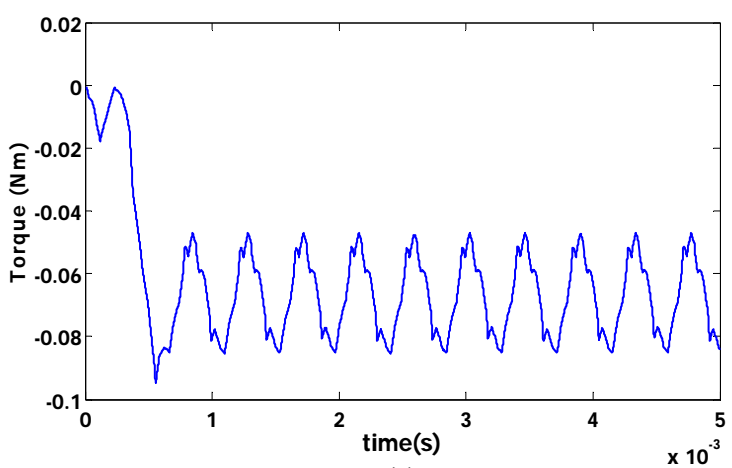

(d)

Figure 4. Profile of (a) current and (b) torque for a three phase 12/8 and (c) current and (d) torque for a three phase 12/16 machine. 
The high number of poles reduces the energy converted per stroke, but it can be compensated by frequent phase excitation. Thus, the high number of poles machine is able to produce the same output power as the lower number of poles machine at the expense of higher iron losses [47]. The combination of the stator and rotor poles is categorized based on the application of the SRG in the low and high speed applications as in Table 1 using the available literatures. It is apparent from Table $\mathbf{1}$ that there is no specific configuration for low speed and high speed operation.

Mueller [53] and Lovatt et al. [56] looked into various number of stator and rotor poles combination. Both findings are similar where it was found that the relative performance such as current density and co-energy will not be affected by increasing the number of poles per phase. They also agree that there is a limit on increasing the number of poles as further increase shows no improvement in performance. According to Mueller, all machine topologies are similar in terms of efficiency and are able to produce the required output power at a given rating. The difference depends on what is required for a particular application. Although the 12/8 machine provides the best power factor and excitation penalty, a 12/16 was preferred by Mueller based on its torque density performance. A new family of the SRM with a higher number of rotor poles than stator poles can be achieved using a pole design (PD) formula [57,58]. It shows a significant improvement in torque per unit volume characteristics with lower ripple as compared to the conventional machine structure which has a higher number of stator poles.

At this stage of research, there is no right combination of stator and rotor poles which gives an optimum output performance. In terms of maintenance and reliability, large number of poles with a large number of phases has the advantages, since fault on one phase may be isolated leaving other phases working, hence less interruption. Apart from that, the current per phase may be reduced by splitting across phases, therefore, lowering the rating of the semiconductor devices per phase [59]. Nevertheless, having a higher number of poles and phases increases the control requirement. The choice of configuration depends on the requirement and types of application.

\section{Control Strategies for SRG}

The generating operation of the machine is said to mirror the operation of the motoring mode [18]. For this reason, similar control strategies can be adopted. However, the control objectives and control implementation of the motoring operation differs for the generating mode [60]. This can be achieved by understanding the motoring operation of the machine. In motoring mode, the excitation of the phase windings is made during the minimum inductance profile. During this time, a high rise of current is expected hence at low speed current chopping mode is employed for overcurrent protection. In contrast to the generating operation, the excitation is made during maximum or increasing inductance profile. The phase current will be low at starting and will slowly increase as the rotor moves away from the stator pole, decreasing the inductance value. Once the signal reaches the turn off angle, the increase in phase current can no longer be controlled. Therefore, the current chopping mode is not suitable for generating operation especially at low speed and under heavy load conditions [61].

The objective of the SRG control is to provide a constant output voltage and power over a wide operating speed range [62]. Several studies investigating the single pulse mode (SPM) operation shows that the firing angles such as the turn on $\left(\mathrm{T}_{\text {on }}\right)$ and turn off $\left(\mathrm{T}_{\text {off }}\right)$ angles are the key elements to improve the performance of the machine in terms of efficiency [63]. Some of the control strategies to determine the turn on and turn off angles uses fuzzy logic [4], flux linkage [64,65] and also curve fitting [55]. The implementation of these firing angles can be grouped into:

- Fixing both turn on and turn off angles;

- One of the angles may be varied whilst keeping the other constant;

- Vary both turn on and turn off angles.

Related studies on the control strategies aim to optimize the machine parameters to maximize the performance. One of the most influential parameters which affect the performance of the machine is the firing angles. It is not a straight forward procedure to determine the optimal firing angles since the machine is highly nonlinear with

Table 1. Typical combination of the stator and rotor pole for SRG.

\begin{tabular}{|c|c|c|c|c|c|c|c|}
\hline \multicolumn{8}{|c|}{ Pole configurations } \\
\hline & $6 / 4$ & $8 / 8$ & $8 / 6$ & $12 / 8$ & $16 / 12$ & $12 / 16$ & $18 / 12$ \\
\hline Low speed & {$[42]$} & {$[43]$} & {$[17,44,45]$} & {$[46]$} & & {$[47]$} & \\
\hline High speed & {$[9,28,29]$} & & {$[21,24,54]$} & {$[27,37,41]$} & {$[55]$} & & {$[25,30]$} \\
\hline One periodic cycle of rotor position & 90 & 45 & 60 & 45 & 30 & 22.5 & 30 \\
\hline
\end{tabular}


both its flux linkage and inductance varying as a function of current and rotor position. Also, the machine is singly excited and may produce a discontinuous current profile [66]. The conditions which may occur during the excitation and generation stages depend on the slope of the inductance, $\frac{\mathrm{d} L}{\mathrm{~d} \theta}$ and amplitude of terminal voltage, $V$ and back EMF, $\omega i \frac{\mathrm{d} L}{\mathrm{~d} \theta}$ as follows:

$$
\pm V=R i+L \frac{\mathrm{d} i}{\mathrm{~d} t}+\omega i \frac{\mathrm{d} L}{\mathrm{~d} \theta}
$$

The terminal voltage will be negative during generating due to the freewheeling current through the diodes. Using the separation of variable method to Equation (6), phase current, $i$ is analyzed as follows:

$$
i=\frac{ \pm V t}{L+\left(R+\omega\left( \pm \frac{\mathrm{d} L}{\mathrm{~d} \theta}\right)\right) t}
$$

where $L$ is the phase inductance, $R$ is the winding resistance, $\omega$ is the angular speed and $t$ is the time. According to Equation (7) the current will slowly increase depending on the voltage level and placement of turn on angle on the inductance slope. The current will start to increase as the rotor moves away from the aligned position. The current will keep on increasing when the back EMF is more than the terminal voltage and slowly extinguish to zero as $\frac{\mathrm{d} L}{\mathrm{~d} \theta}$ approaches the minimum value. From Equation (7), the parameters which may increase the phase current are speed, voltage, placement of firing angles and also reference current. As can be seen, there are several parameters affecting the phase current hence it is not a straight forward procedure to determine the optimal firing angles for SRG. After turn off angle, the phase current may increase or decrease depending on the amount of stored energy and back EMF as shown in Figure 5. By placing the turn on angle before the alignment position allows the current to build up as depicted in Figure 5(d). However, if the turn on angle is placed

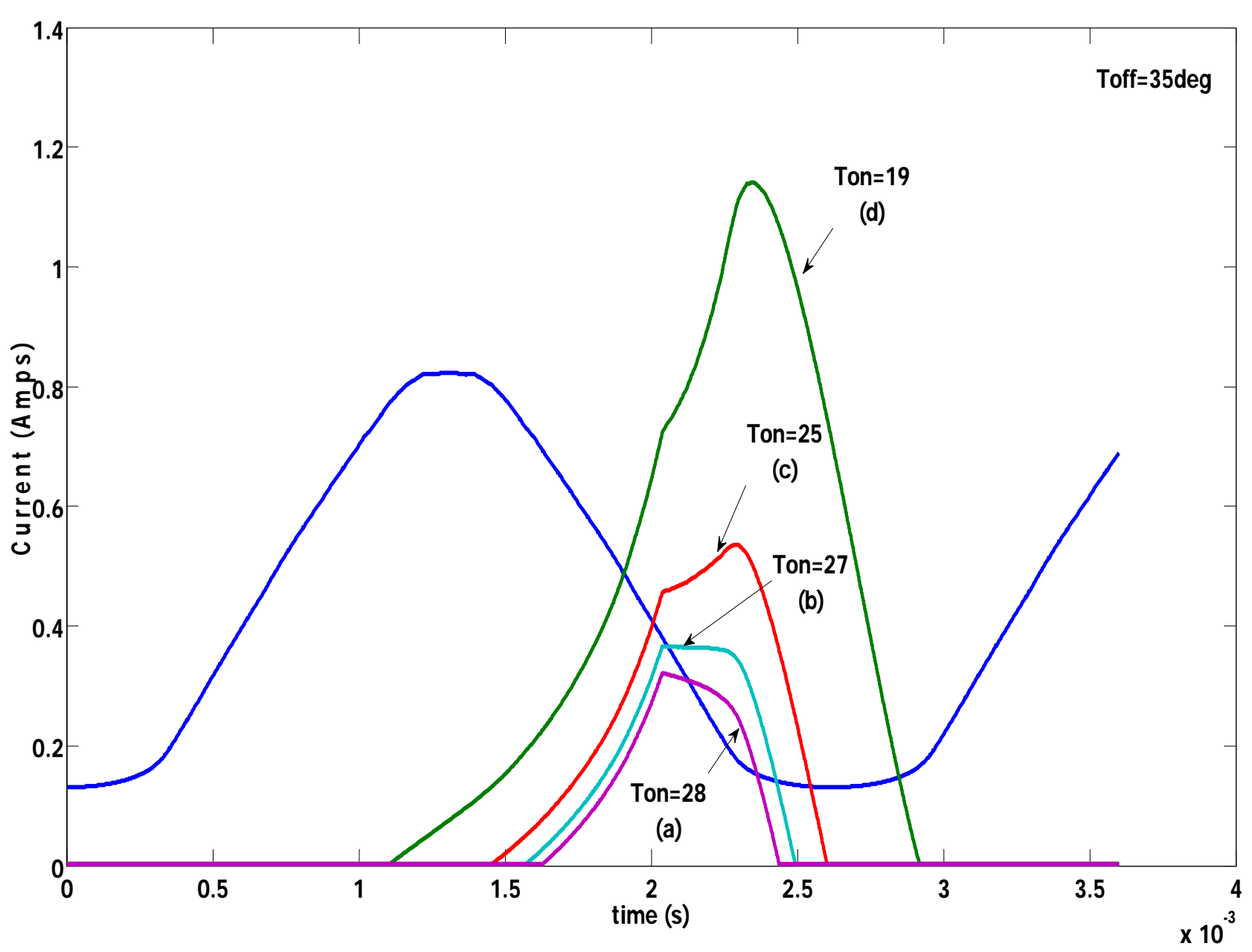

Figure 5. Variation of phase current with respect to inductance profile. 
too far in the increasing inductance region, the generating current will tail off in the next phase of excitation and may reduce the generated power. If the turn off angle is held constant, whilst the turn on angle is moved along the decreasing inductance profile, the dwell angle, which is the difference between the turn off and turn on angle reduces as shown in Figures 5(a)-(c). This too will reduce the power generated by the machine. As can be seen, it is not a straight procedure to determine the optimal angles for SRG. Therefore, various control strategies have been proposed to determine the optimal values of firing angles based on the specified criteria.

\subsection{High Speed}

For the aircraft and automotive industry, the generating operation is required to supply DC electrical power to various vehicle engine and loads; therefore, the control objectives are to maintain the DC link voltage within the specified limit [27]. This can be achieved by using a voltage feedback control loop coupled with a PI controller. The control system using the turn on angle as the output of a PI controller yield a linear function of DC current versus turn on angle for various speed [29]. In [9], a fixed firing angles are used to generate the necessary current to maintain the bus voltage. The turn off angle can be characterized as a function of power and speed in [55]. An analytical curve is used to determine optimal turn off angle whereas turn on angle is adjusted to regulate the power. It is assumed that the machine gives optimal efficiency once optimal turn off angle has been determined. Mese et al. [67] uses a mapping strategy to determine turn on and turn off angles that produce maximum power based on a minimum RMS phase current. Heuristic selection algorithm is used to identify the optimal angles hence the method is rather time consuming. Furthermore, it did not include any development of a function relating the optimized parameters with machine performance. Similarity between the methods above involves the use of phase current as a state variable. A simple formula to compromise the performance between high efficiency and low torque ripple has been proposed using flux linkage control. It can be used for both the single pulse [62] and current chopping mode [64]. The method assumes excitation period equals generation period at constant speed and relies heavily on the flux, current and inductance profile to determine the intersection angles of the maximum flux and peak current. Also, the output power generated catered for a specific load requirement. A capacitive output filter is designed together with the voltage feedback control to reduce the voltage ripple [68]. A new control method using multi-objective optimization function was proposed to accomplish three criteria including high torque, high operating efficiency and also low torque ripple for an electric vehicle application [54]. For those reported methods, in summary, the objectives were confined to maximize torque production, minimize losses and also to minimize torque ripple.

\subsection{Low Speed}

The control strategies for wind energy application are mostly based on speed feedback control. The strategies such as the current chopping mode [43] and pulse width modulated method (PWM) are employed to allow the initial current to reach the reference value especially at the low speeds where the back EMF is small [17]. There are not many literatures, which focus on the low and medium speed operation. As mentioned earlier, the common chopping mode for motoring is not suitable for the generating operation unless a high value of power is required. The current chopping mode control method is normally used at low speed for the wind energy conversion system (WECS) application [44,47]. The WECS application ensures an optimum operation of the wind turbine for a particular wind speed by relying on the conversion coefficient of the turbine. The method, however requires measurement of wind speed [45]. A power control strategy was used to maintain the required load demand. Another method to control the output power is achieved by using a fuzzy logic controller to regulate the turn on angle whilst the turn off angle is kept constant [46]. The resources on the application of the machine for the control strategies in wind energy are still limited. The method based on constant output power requires the machine to follow the set of reference power. This limits the potential of the machine to extract energy according to the wind velocity.

\section{Power Converter for SRG}

As the control between the motoring and generating operation differs in terms of objectives, the same converter topology can be employed. The end windings of each phase will be connected to a converter circuit. The converter circuit controls the phase current through the windings by providing a path through the switches during excitation and diodes during generating operation. Therefore, the operation of the machine during one cycle can be categorized as two stages: excitation and generation. The switching strategy has an impact on the efficiency of the SRG [69].

The commonly described converter circuit for the SRG is the Asymmetric Half Bridge Converter (AHBC) consisting of two switching devices and two power diodes per phase. The implication of using a higher number of switching devices per phase limits the number of phases for a machine in terms of space constraint/cost. There have been studies on alternative converters for SR ge- 
nerator using a reduced number of devices. In [70], a converter topology having one number of switch and diode per phase allows the load to be supplied from the grid even when the SR generator is not running. Unlike the conventional AHBC converter, the supply voltage will be in series with the back EMF during the generation process supplying load continuously. It is only suitable for constant speed applications. Another converter topology with a reduced number of devices was proposed in [71]. The operating characteristic of the new proposed suppression resistor converter topology is similar to a conventional AHBC; however, it is only suitable for a single pulse mode operation. Aside from generating DC power, the SR generator can also be used to regenerate AC power using a sparse converter [72]. This opens a new research area in terms of generating AC voltage using SR generator.

On the whole, the researchers on converter topology for generating operation focus on ways to reduce the number of semiconductor devices. The aim is to minimize costs and size of the overall device. However, with a reduced number of switching devices, the converter is not flexible in terms of control. This might be one of the reasons that although new topologies have been suggested, researchers still choose the conventional AHBC converter. The generating cycle determines the type of converter to be used for a particular application. Since current chopping mode is not suitable for generating operation, the reduced number of the converter can be selected in an effort to reduce cost and save on space. At the moment, there is no specific converter topology which has been assigned to either the low or high speed application.

\section{Conclusions}

Based on the application of the machine, the operation of the switched reluctance generator can be categorized into the low and medium speed operation and high speed operation. The operation of the machine at high speed can exceed the speed of 20,000 rpm for the aerospace applications, which is beyond the speed encountered in wind energy system, which could be as low as $200 \mathrm{rpm}$. Overall, the previous studies have acknowledged the potential of the SRG as one of the candidates for variable speed applications. However, the available research in the generating operation mainly covers the high speed application. Unlike its motoring counterpart, the commercial application of the machine as a generator is still limited.

The objective of this paper is to provide an overview of the machine in generating mode focusing on its application, machine structure, control strategies and also converter topology employed. It can be concluded that the existing research on SRG is mainly focused on enhancing the performance of the machine based on the individual element of the drive such as the control, converter and also the machine geometry. For such specific study, which does not require many changes on the machine parameters, an experimental set up is feasible. However, to analyze the machine thoroughly, various changes on the parameters have to be made. This would incur high cost and would be time consuming if the changes were to be performed during the experimental stage. Hence, to date there is still no specific controller, converter or machine configurations which have been proposed for the generating operation.

The development of the SRG lacks a platform which enables researchers to perform analysis on the overall system before developing the machine prototype. To aid in the development of the SRG and to close the commercial gap between the existing machines a simulation platform of the overall system is required.

The research on improving the performance of the $\mathrm{SRG}$ is far from exhausted. It has taken years of research before the existing generators penetrates the market, the same will be for the new generations of machine. Further research is required to fill the commercial gap with the SRG and with the aid of a comprehensive modeling software, an in depth analysis of SRG will improve its performance and acceptance.

\section{REFERENCES}

[1] T. J. E. Miller, "Electronic Control of Switched Reluctance Machines," Newnes, Oxford, 2001.

[2] R. Krishnan, "Switched Reluctance Motor Drives: Modeling, Simulation, Analysis, Design, and Applications," CRC Press, Taylor \& Francis Group, Boca Raton, 2001. doi:10.1201/9781420041644

[3] C. Pollock and A. Michaelides, "Switched Reluctance Drives: A Comparative Evaluation," Power Engineering Journal, Vol. 9, No. 6, 1995, pp. 257-266. doi:10.1049/pe: 19950606

[4] H. Chen, "Implementation of a Three-Phase Switched Reluctance Generator System for Wind Power Applications," 14th Symposium on Electromagnetic Launch Technology, Victoria, 10-13 June 2008, pp. 1-6. doi:10.1109/ELT.2008.104

[5] J. Briso-Montiano, R. Karrelmeyer and E. Dilger, "Simulation of Faults by Means of Finite Element Analysis in a Switched Reluctance Motor," COMSOL Multiphysics User's Conference, Frankfurt, 2-4 November 2005, pp. 225-231.

[6] I. Husain, A. Radun and J. Nairus, "Fault Analysis and Excitation Requirements for Switched Reluctance-Generators," IEEE Transactions on Energy Conversion, Vol. 17, No. 1, 2002, pp. 67-72. doi:10.1109/60.986439

[7] T. J. E. Miller, "Faults and Unbalance Forces in the Switched Reluctance Machine," Conference Record of the 1993 IEEE Industry Applications Society Annual Meeting, Toronto, 2-8 October 1993, pp. 87-96.

[8] M. Krishnamurthy, C. S. Edrington, A. Emadi, P. Asadi, 
M. Ehsani and B. Fahimi, "Making the Case for Applications of Switched Reluctance Motor Technology in Automotive Products," IEEE Transactions on Power Electronics, Vol. 21, No. 3, 2006, pp. 659-675. doi:10.1109/TPEL.2006.872371

[9] C. A. Ferreira, S. R. Jones, W. S. Heglund and W. D. Jones, "Detailed Design of a 30-kW Switched Reluctance Starter/Generator System for a Gas Turbine Engine Application," IEEE Transactions on Industry Applications, Vol. 31, No. 3, 1995, pp. 553-561. doi: $10.1109 / 28.382116$

[10] K. Vijayakumar, R. Karthikeyan, S. Paramasivam, R. Arumugam and K. N. Srinivas, "Switched Reluctance Motor Modeling, Design, Simulation, and Analysis: A Comprehensive Review," IEEE Transactions on Magnetics, Vol. 44, No. 12, 2008, pp. 4605-4617. doi:10.1109/TMAG.2008.2003334

[11] D. Wen and L. Deliang, "Modeling of a 6/4 Switched Reluctance Motor Using Adaptive Neural Fuzzy Inference System," IEEE Transactions on Magnetics, Vol. 44, No. 7, 2008, pp. 1796-1804. doi:10.1109/TMAG.2008.919711

[12] I. Husain and S. A. Hossain, "Modeling, Simulation, and Control of Switched Reluctance Motor Drives," IEEE Transactions on Industrial Electronics, Vol. 52, No. 6, 2005, pp. 1625-1634. doi:10.1109/TIE.2005.858710

[13] K. R. Geldhof, T. J. Vyncke, F. M. L. L. De Belie, L. Vandevelde, J. A. A. Melkebeek and R. K. Boel, "Embedded Runge-Kutta Methods for the Integration of a Current Control Loop in an SRM Dynamic Finite Element Model," Science, Measurement \& Technology, IET, Vol. 1, No. 1, 2007, pp. 17-20. doi:10.1049/iet-smt:20060026

[14] E. Echenique, J. Dixon, R. Cardenas and R. Pena, "Sensorless Control for a Switched Reluctance Wind Generator, Based on Current Slopes and Neural Networks," IEEE Transactions on Industrial Electronics, Vol. 56, No. 3, 2009, pp. 817-825. doi:10.1109/TIE.2008.2005940

[15] A. Kawamura, "Survey of Position Sensorless Switched Reluctance Motor Control," 20th International Conference on Industrial Electronics, Control and Instrumentation (IECON), Bologna, 5-9 September 1994, pp. 15951598.

[16] V. R. Bernardeli, D. A. Andrade, A. W. F. V. Silveira, L. C. Gomes, G. P. Viajante and L. G. Cabral, "Self-Excited Switched Reluctance Generator," Brazilian Power Electronics Conference (COBEP), Praiamar, 11-15 September 2011, pp. 55-60.

[17] M. Nassereddine, J. Rizk and M. Nagrial, "Switched Reluctance Generator for Wind Power Applications," Proceedings of World Academy of Science, Engineering and Technology, Atlanta, 18-22 June 1995, pp. 559-564.

[18] A. Radun, "Generating with the Switched Reluctance Motor," 9th Annual Conference Proceedings of Applied Power Electronics Conference and Exposition (APEC) Orlando, 13-17 February 1994, pp. 41-47.

[19] J. Coles and C. Williams, "Switched Reluctance Generator and a Method of Controlling Such a Generator," 2002. http://www.freepatentsonline.com/EP1236269.html
[20] M. Liptak, V. Hrabovcova and P. Rafajdus, "Equivalent Circuit of Switched Reluctance Generator Based on DC Series Generator," Journal of Electrical Engineering, Vol. 59, No. 1, 2008, pp. 23-28.

[21] P. S. J. R. French, "Switched Reluctance Motor Drives for Rail Traction: Relative Assessment," IEE Proceedings B on Electric Power Applications, Vol. 131, No. 5, 1984, pp. 209-219.

[22] C. C. Chan, "The State of the Art of Electric and Hybrid Vehicles," Proceedings of the IEEE, Vol. 90, No. 2, 2002, pp. 247-275. doi:10.1109/5.989873

[23] M. Ehsani, K. M. Rahman and H. A. Toliyat, "Propulsion System Design of Electric and Hybrid Vehicles," IEEE Transactions on Industrial Electronics, Vol. 44, No. 1, 1997, pp. 19-27. doi:10.1109/41.557495

[24] W. Shuanghong, Z. Qionghua, M. Zhiyuan and Z. Libing, "Implementation of a 50-kW Four-Phase Switched Reluctance Motor Drive System for Hybrid Electric Vehicle," IEEE Transactions on Magnetics, Vol. 41, No. 1, 2005, pp. 501-504. doi:10.1109/TMAG.2004.838985

[25] M. Takeno, A. Chiba, N. Hoshi, S. Ogasawara, M. Takemoto and M. A. Rahman, "Test Results and Torque Improvement of the $50-\mathrm{kW}$ Switched Reluctance Motor Designed for Hybrid Electric Vehicles," IEEE Transactions on Industry Applications, Vol. 48, No. 4, 2012, pp. 1327-1334. doi:10.1109/TIA.2012.2199952

[26] A. V. Radun, "High Power Density Switched Reluctance Motor Drive for Aerospace Applications," Conference Record of the 1989 IEEE Industry Applications Society Annual Meeting, San Diego, 1-5 October 1989, pp. 568573.

[27] E. Richter and C. Ferreira, "Performance Evaluation of a 250 kW Switched Reluctance Starter Generator," IEEE Industry Applications Conference Record, Orlando, 10 August-10 December 1995, pp. 434-440.

[28] S. R. MacMinn and W. D. Jones, "A Very High Speed Switched-Reluctance Starter-Generator for Aircraft Engine Applications," Proceedings of the IEEE $1989 \mathrm{Na}$ tional Aerospace and Electronics Conference, Dayton 22-26 May 1989, pp. 1758-1764. doi:10.1109/NAECON.1989.40453

[29] S. R. MacMinn and J. W. Sember, "Control of a Switched-Reluctance Aircraft Engine Starter-Generator over a Very Wide Speed Range," Proceedings of the 24th Intersociety Energy Conversion Engineering Conference, Washington DC, 6-11 August 1989, pp. 631-638. doi:10.1109/IECEC.1989.74532

[30] N. Schofield and S. Long, "Generator Operation of a Switched Reluctance Starter/Generator at Extended Speeds," IEEE Transactions on Vehicular Technology, Vol. 58, No. 1, 2009, pp. 48-56. doi:10.1109/TVT.2008.924981

[31] B. Fahimi, "A Switched Reluctance Machine Based Starter/ Generator for More Electric Cars," IEEE International Electric Machines and Drives Conference (IEMDC), Cambridge, 17-20 June 2001, pp. 73-78.

[32] W. Cai, "Comparison and Review of Electric Machines for Integrated Starter Alternator Applications," 39th IAS Annual Meeting in Industry Applications Conference, Seattle, 3-7 October 2004, p. 393. 
doi:10.1109/IAS.2004.1348437

[33] A. Emadi, S. S. Williamson and A. Khaligh, "Power Electronics Intensive Solutions for Advanced Electric, Hybrid Electric, and Fuel Cell Vehicular Power Systems," IEEE Transactions on Power Electronics, Vol. 21, No. 3, 2006, pp. 567-577.

doi:10.1109/TPEL.2006.872378

[34] A. Walker, P. Anpalahan, P. Coles, M. Lamperth and D. Rodgert, "Automotive Integrated Starter Generator," 2nd International Conference on Power Electronics, Machines and Drives (PEMD), Edinburgh, 31 March-2 April 2004, pp. 46-48.

[35] I. Boldea, "Control of Electric Generators: A Review," The 29th Annual Conference of the IEEE Industrial Electronics Society (IECON), Roanoke, 2-6 November 2003, pp. 972-980.

[36] B. Fahimi, A. Emadi and R. B. Sepe Jr., "A Switched Reluctance Machine-Based Starter/Alternator for More Electric Cars," IEEE Transactions on Energy Conversion, Vol. 19, No. 1, 2004, pp. 116-124. doi:10.1109/TEC.2003.822322

[37] J. Faiz and K. Moayed-Zadeh, "Design of Switched Reluctance Machine for Starter/Generator of Hybrid Electric Vehicle," Electric Power Systems Research, Vol. 75, No. 2-3, 2005, pp. 153-160. doi:10.1016/j.epsr.2005.02.004

[38] Z. Q. Zhu and D. Howe, "Electrical Machines and Drives for Electric, Hybrid, and Fuel Cell Vehicles," Proceedings of the IEEE, Vol. 95, No. 4, 2007, pp. 746-765. doi:10.1109/JPROC.2006.892482

[39] S. Song, W. Liu and U. Schaefer, "Thermal Analysis of a $30 \mathrm{~kW}$ Switched Reluctance Starter/Generator System Used in Aircraft," International Conference on Power Engineering, Energy and Electrical Drives (POWERENG), Lisbon, 18-20 March 2009, pp. 331-336. doi:10.1109/POWERENG.2009.4915170

[40] J. A. Weimer, "Electrical Power Technology for the More Electric Aircraft," 12th Digital Avionics Systems Conference (DASC), Fort Worth, 25-28 October 1993, pp. 445450.

[41] A. V. Radun, C. A. Ferreira and E. Richter, "Two-Channel Switched Reluctance Starter/Generator Results," IEEE Transactions on Industry Applications, Vol. 34, No. 5, 1998, pp. 1026-1034. doi:10.1109/28.720442

[42] A. Fleury, D. A. de Andrade, F. dos Santos e Silva and J. L. Domingos, "Switched Reluctance Generator for Complementary Wind Power Generation in Grid Connection," IEEE International Electric Machines \& Drives Conference, Antalya, 3-5 May 2007, pp. 465-470.

[43] Q. Zhang, X. Wang, X. Zhu and D. Liu, "A Small Single-Phase Switched Reluctance Generator for Wind Power Generation," Proceedings of the 5th International Conference on Electrical Machines and Systems, Shenyang, 18-20 August 2001, pp. 1003-1006.

[44] R. Cardenas, R. Pena, M. Perez, J. Clare, G. Asher and P. Wheeler, "Control of a Switched Reluctance Generator for Variable-Speed Wind Energy Applications," IEEE Transactions on Energy Conversion, Vol. 20, No. 4, 2005, pp. 781-791. doi:10.1109/TEC.2005.853733

[45] R. Cardenas, W. F. Ray and G. M. Asher, "Switched
Reluctance Generators for Wind Energy Applications," 26th Annual IEEE Power Electronics Specialists Conference (PESC), Atlanta, 18-22 June 1995, pp. 559-564.

[46] H. Chen and Z. Shao, "Turn-on Angle Control for Switched Reluctance Wind Power Generator System," The 30th Annual Conference of IEEE Industrial Electronics Society (IECON), Busan, 2-6 November 2004, pp. 23672370.

[47] M. Mueller, "Design and Performance of a $20 \mathrm{~kW}, 100$ rpm, Switched Reluctance Generator for a Direct Drive Wind Energy Converter," IEEE International Conference on Electric Machines and Drives, San Antonio, 15 May 2005, pp. 56-63.

[48] C. Bratiloveanu, D. Anghelus and I. Boldea, "A Comparative Investigation of Three PM-Less MW Power Range Wind Generator Topologies," 13th International Conference on Optimization of Electrical and Electronic Equipment (OPTIM), Brasov, 24-26 May 2012, pp. 535543.

[49] K. Ogawa, N. Yamamura and M. Ishda, "Study for Small Size Wind Power Generating System Using Switched Reluctance Generator," IEEE International Conference on Industrial Technology, Mumbai, 15-17 December 2006, pp. 1510-1515. doi:10.1109/ICIT.2006.372468

[50] J.-B. Hu and Y.-K. He, "Dynamic Modelling and Robust Current Control of Wind-Turbine Driven DFIG during External AC Voltage Dip," Journal of Zhejiang University-Science A, Vol. 7, No. 10, 2006, pp. 1757-1764.

[51] T. J. E. Miller, "Optimal Design of Switched Reluctance Motors," IEEE Transactions on Industrial Electronics, Vol. 49, No. 1, 2002, pp. 15-27. doi:10.1109/41.982244

[52] M. K. El-Nemr, M. A. Al-Khazendar, E. M. Rashad and M. A. Hassanin, "Modeling and Steady-State Analysis of Stand-Alone Switched Reluctance Generators," IEEE Power Engineering Society General Meeting, 13-17 July 2003, p. 1899.

[53] M. A. Mueller, "Design of Low Speed Switched Reluctance Machines for Wind Energy Converters," 9th International Conference on Electrical Machines and Drives, Canterbury, 1-3 September 1999, pp. 60-64. doi:10.1049/cp:19990991

[54] X. D. Xue, K. W. E. Cheng, J. K. Lin, Z. Zhang, K. F. Luk, T. W. Ng and N. C. Cheung, "Optimal Control Method of Motoring Operation for SRM Drives in Electric Vehicles," IEEE Transactions on Vehicular Technology, Vol. 59, No. 3, 2010, pp. 1191-1204. doi:10.1109/TVT.2010.2041260

[55] Y. Sozer and D. A. Torrey, "Closed Loop Control of Excitation Parameters for High Speed Switched-Reluctance Generators," IEEE Transactions on Power Electronics, Vol. 19, No. 2, 2004, pp. 355-362. doi:10.1109/TPEL.2003.823178

[56] H. C. Lovatt and J. M. Stephenson, "Influence of Number of Poles per Phase in Switched Reluctance Motors," IEE Proceedings B on Electric Power Applications, Vol. 139, No. 4, 1992, pp. 307-314.

[57] P. C. Desai, M. Krishnamurthy, N. Schofield and A. Emadi, "Novel Switched Reluctance Machine Configuration with Higher Number of Rotor Poles than Stator Poles: 
Concept to Implementation," IEEE Transactions on Industrial Electronics, Vol. 57, No. 2, 2010, pp. 649-659. doi:10.1109/TIE.2009.2034678

[58] B. Bilgin, A. Emadi and M. Krishnamurthy, "Design Considerations for Switched Reluctance Machines with a Higher Number of Rotor Poles," IEEE Transactions on Industrial Electronics, Vol. 59, No. 10, 2012, pp. 37453756. doi:10.1109/TIE.2011.2141102

[59] E. Levi, "Multiphase Electric Machines for VariableSpeed Applications," IEEE Transactions on Industrial Electronics, Vol. 55, No. 5, 2008, pp. 1893-1909. doi:10.1109/TIE.20

[60] D. A. Torrey, "Switched Reluctance Generators and Their Control," IEEE Transactions on Industrial Electronics, Vol. 49, No. 1, 2002, pp. 3-14. doi:10.1109/41.982243

[61] Y.-C. Chang and C.-M. Liaw, "On the Design of Power Circuit and Control Scheme for Switched Reluctance Generator," IEEE Transactions on Power Electronics, Vol. 23, No. 1, 2008, pp. 445-454. doi:10.1109/TPEL.2007.911872

[62] I. Kioskeridis and C. Mademlis, "Optimal Efficiency Control of Switched Reluctance Generators," IEEE Transactions on Power Electronics, Vol. 21, No. 4, 2006, pp. 1062-1072. doi:10.1109/TPEL.2006.876827

[63] P. Asadi, M. Ehsani and B. Fahimi, "Design and Control Characterization of Switched Reluctance Generator for Maximum Output Power," 21st Annual IEEE Applied Power Electronics Conference and Exposition, Dallas Texas, 19-23 March 2006, pp. 1639-1644.

[64] C. Mademlis and I. Kioskeridis, "Optimizing Performance in Current-Controlled Switched Reluctance Generators," IEEE Transactions on Energy Conversion, Vol. 20, No. 3, 2005, pp. 556-565. doi:10.1109/TEC.2005.852960

[65] I. Kioskeridis and C. Mademlis, "Maximum Efficiency in Single-Pulse Controlled Switched Reluctance Motor Drives," IEEE Transactions on Energy Conversion, Vol. 20, No. 4, 2005, pp. 809-817.

\section{doi:10.1109/TEC.2005.853738}

[66] H. Hannoun, M. Hilairet and C. Marchand, "Experimental Validation of a Switched Reluctance Machine Operating in Continuous-Conduction Mode," IEEE Transactions on Vehicular Technology, Vol. 60, No. 4, 2011, pp. 14531460. doi:10.1109/TVT.2011.2124478

[67] E. Mese, Y. Sozer, J. M. Kokernak and D. A. Torrey, "Optimal Excitation of a High Speed Switched Reluctance Generator," 15th Annual IEEE Applied Power Electronics Conference and Exposition (APEC), New Orleans, 6-10 February 2000, pp. 362-368. doi:10.1109/APEC.2000.826128

[68] Y.-C. Chang and C.-M. Liaw, "Development and Voltage Feedback Control for a Switched Reluctance Generator," International Conference on Electrical Machines and Systems (ICEMS), Seoul, 26 December 2007, pp. 392397.

[69] E. Elwakil and M. Darwish, "Critical Review of Converter Topologies for Switched Reluctance Motor Drives," International Review of Electrical Engineering, Vol. 2, No. 1, 2007, pp. 50-58.

[70] E. S. L. Oliveira, A. Fleury, G. A. Fleury-Neto and T. F. Oliveira, "Performance Comparison of an Alternative Converter for Wind Powered Switched Reluctance Generators," International Conference on Renewable Energies and Power Quality (ICREPQ), Santander, 12-14 March 2008, pp. 1-6.

[71] A. Takahashi, H. Goto, K. Nakamura, T. Watanabe and O. Ichinokura, "Characteristics of 8/6 Switched Reluctance Generator Excited by Suppression Resistor Converter," IEEE Transactions on Magnetics, Vol. 42, No. 10, 2006, pp. 3458-3460. doi:10.1109/TMAG.2006.880388

[72] N. K. Singh, J. E. Fletcher, S. J. Finney, D. M. Grant and B. W. Williams, "Evaluation of Sparse PWM Converter for Switched Reluctance Generator," International Conference on Power Electronics and Drives Systems, Kuala Lumpur, 28 November-1 December 2005, pp. 721-725. 